\title{
Model Pembelajaran Berbasis Penstimulasian Multiple Intelligences Siswa
}

\author{
Edy Legowo \\ Program Studi Bimbingan dan Konseling, Fakultas Keguruan Ilmu Pendidikan, Universitas Sebelas Maret, \\ Jl. Ir Sutami No. 36A, Surakarta, Jawa Tengah, Indonesia 57126 \\ E-mail: legowobk@gmail.com
}

Artikel diterima: 17 Januari 2017; direvisi 3 Maret 2017; disetujui 9 Maret 2017

\begin{abstract}
Abstrak: Tulisan ini membahas mengenai penerapan teori multiple intelligences dalam pembelajaran di sekolah. Pembahasan diawali dengan menguraikan perkembangan konsep inteligensi dan multiple intelligences. Diikuti dengan menjelaskan dampak teori multiple intelligences dalam bidang pendidikan dan pembelajaran di sekolah. Bagian selanjutnya menguraikan tentang implementasi teori multiple intelligences dalam praktik pembelajaran di kelas yaitu bagaimana pemberian pengalaman belajar siswa yang difasilitasi guru dapat menstimulasi multiple intelligences siswa. Evaluasi hasil belajar siswa dari pandangan penerapan teori multiple intelligences seharusnya dilakukan menggunakan authentic assessment dan portofolio yang lebih memfasilitasi para siswa mengungkapkan atau mengaktualisasikan hasil belajarnya melalui berbagai cara sesuai dengan kekuatan jenis inteligensinya.
\end{abstract}

Kata kunci: multiple intelligences; pembelajaran; performasi akademik

Tulisan ini membahas mengenai teori multiple intelligences dalam penerapannya di sekolah khususnya dalam proses memberikan pengalaman belajar yang menekankan upaya menstimulasi kekuatan inteligensi siswa. Melalui penstimulasian kekuatan inteligensi siswa dalam proses belajar diharapkan mereka dapat menerima dan mengolah informasi dengan mudah, dan mampu menunjukkan hasil belajar sesuai dengan gaya belajarnya masing-masing. Pemberian pengalaman belajar yang demikian tersebut jauh berbeda dengan proses pembelajaran konvensional di sekolah. Di tahun 1980-an Goodlad (dalam Armstrong, 2002) bersama rekan-rekannya mengunjungi sekitar 1000 ruang kelas di Amerika Serikat (AS). Deskripsi yang dibuat atas hasil kunjungan mereka tersebut yaitu dunia gersang tanpa kegembiraan dalam skala besar. Dikemukakan selanjutnya bahwa semua ruang kelas Sekolah Dasar didominasi oleh guru, sedangkan murid tidak berwenang menentukan apa-apa. Keadaan menjadi semakin buruk di era tahun 1990-an, ada gerakan menjadikan situasi ruang kelas menjadi lebih suram. Buku pelajaran dan lembar kerja membentuk $75 \%$ hingga $90 \%$ dari semua waktu proses belajar di sekolah. Siswa di AS adalah siswa yang paling sering dites di seluruh dunia. Kondisi semacam ini nampaknya masih sangat terasa terjadi di sekolah Indonesia dewasa ini. Durasi waktu yang didominasi pada "duduk, dengar, catat", tugas PR yang semua itu merupakan hidangan pengalaman belajar yang menjemukan, membuat anak stres, dan hasil belajarnya pun hanya mencapai level kognitif rendah. Demikian halnya yang terjadi di kursus-kursus atau lembaga bimbingan belajar di masyarakat.

Pembelajaran dengan pendekatan multiple intelligences merupakan upaya memberikan pengalaman belajar yang dirancang selaras dengan kebutuhan, gaya kognisi siswa, khususnya sesuai dengan kekuatan jenis inteligensi setiap siswa. Pendekatan pembelajaran penstimulasian multiple intelligences mengasumsikan bahwa setiap anak cerdas, namun kecerdasan mereka bervariasi. 
Sebagian mereka memiliki kekuatan satu atau lebih jenis inteligensi (misalnya kuat dalam inteligensi spasial dan logical-mathematic, sementara yang lain kuat dalam inteligensi interpersonal dan bodykinesthetic, lainnya lagi kuat dalam musikal dan naturalis). Dengan kata lain, mereka memiliki gaya belajar atau cara mudah belajar yang bervariasi. Pendekatan pembelajaran multiple intelligences diharapkan dapat memfasilitasi variasi kekuatan inteligensi dan gaya belajar setiap siswa, sehingga pada gilirannya mereka dapat mencapai prestasi optimal dan tumbuh sikap cinta belajar.

Permasalahan proses pembelajaran yang terjadi di sekolah-sekolah pada umumnya di satu dan di sisi lain perlu adanya solusi. Proses pembelajaran melalui penstimulasian multiple intelligences sebagai solusi, akan diuraikan mengenai: (1) konsep multiple intelligences; (2) dampak teori multiple intelligences dalam dunia pendidikan dan pembelajaran; dan (3) evaluasi hasil belajar berbasis multiple intelligences.

\section{KONSEP MULTIPLE INTELLIGENCES}

Sejak dikembangkan tes inteligensi oleh Binet dan Simon di Perancis pada awal tahun 1900-an, tes inteligensi begitu populer. Ketika itu, konsep inteligensi diartikan sebagai kekuatan intelektual yang diwariskan dan permanen. Dalam perkembangannya inteligensi dipahami sebagai gabungan faktor bawaan dan lingkungan. Pandangan ini tercermin dari pernyataan Ramey (dalam Rose \& Nicholl, 1997) bahwa pengalaman menstimulasi mental secara positif pada awal masa anak dapat menambah 20 poin skor intelligence quotient sebelumnya. Pandangan inteligensi tersebut diistilahkan sebagai "raw intelligence" yang fenomenanya berupa skor intelligence quotient (Carvin, 2000). Pada saat itu, salah satu alat tes yang populer digunakan mengukur intelligence quotient seseorang yaitu Scholastic Aptitude Test (SAT). Hasil pengukuran dengan alat tes tersebut dipergunakan untuk dasar memprediksikan prestasi belajar siswa dikemudian hari atau untuk memprediksi kemampuan mereka apakah layak atau tidak layak melanjutkan studi di perguruan tinggi.

Berbeda dengan pengkonsepsian inteligensi di atas adalah jawaban atas pertanyaan "Siapa orang yang dikategorikan inteligen?" Seseorang disebut inteligen bilamana memiliki general intelectual yaitu kemampuan memahami, memeriksa, dan merespon stimulus dari luar, apakah stimulus itu berupa tugas memecahkan soal matematika, mengantisipasi gerakan lawan dalam permainan tenis, keterampilan memainkan alat musik, kemampuan melakukan negosiasi bidang bisnis, kemampuan berorasi sehingga ia berhasil dalam karir politiknya, dan sejenisnya. Dalam pemaknaan inteligensi seperti di atas dapat disimpulkan bahwa inteligensi merupakan kemampuan kolektif yang dimiliki setiap individu untuk bertindak dan bereaksi terhadap perubahan yang terjadi di masyarakat.

Pemahaman terhadap pengertian inteligensi yang disebut terakhir, Carvin (2000), memaknainya sebagai " ... a pluralized way of understanding the intelect"; dan Gardner (1993) menyatakan bahwa "...multiple intelligences theory, on the other hand, pluralizes the traditional concept"; sedangkan Lazear (1990) menyatakan bahwa "Intelligence is multiple reality that occurs in different parts of the brain/mind system". Sementara hasil penelitian bidang kognitif merefleksikan keyakinan bahwa "...intelligence is not a monolithic quality, but has multiple component" (Tsantis \& Keefe dalam Collin \& Mangieri, 1992). Robert Sternberg telah pula membedakan secara kualitatif jenis inteligensi menjadi: inteligensi componential (diukur dengan tes inteligensi tradisional), contextual (kapasitas untuk memahami dengan kreatif), dan experiential (inteligensi "the street smart")(dalam Collin \& Mangieri, 1992). Dengan kata lain, inteligensi merupakan suatu kemampuan yang bersifat jamak sebagai hasil perkembangan ilmu pengetahuan kognitif, psikologi perkembangan, dan neuroscience. Tiga bidang ilmu tersebut menyimpulkan bahwa inteligensi seseorang sebenarnya merupakan swatantra kecakapan (faculties) yang dapat bekerja secara individual atau secara "berorkestra" dengan yang lain (Carvin, 2000).

Dalam pengertian inteligensi adalah jamak, lebih dari 30 tahun silam Howard Gardner mengembangkan teori inteligensi yang berbeda dengan teori inteligensi berkarakteristik tunggal. Pada mulanya, Gardner mendefinisikan inteligensi adalah "An intelligence entails the ability to solve problems or fashion products that are consequence in a particular cultural setting or 
community" (Gardner, 1993). Selanjutnya, Gardner meredefinisi pengertian inteligensi sebagai “...a biopsychological potential to process information that can be activated in cultural setting to solve problems or create products that are value in a cultural" (Gardner, 1999). Konsep inteligensi jamak ini memiliki cakupan yang luas, berperspektif sebagai strategi pembelajaran dan meninggalkan konsep inteligensi yang mistik menjadi konsep inteligensi yang fungsional (Armstrong, 1994).

Teori multiple intelligences telah mengidentifikasi 7 jenis inteligensi yaitu: inteligensi verballinguistic, logical-mathematic, spatial, musical, bodily-kinestetic, interpersonal, intrapersonal (Gardner, 2003), kemudian pada akhir tahun 1990-an diidentifikasi inteligensi kedelapan yaitu naturalistic intelligence (Rose dan Nicholl, 1997, Gardner 1999), dan pada tahun yang sama Gardner telah mempertimbangkan inteligensi kesembilan dan kesepuluh yaitu existential intelligence dan spiritual intelligence (Carvin, 2000). Gardner tidak pernah membuat aturan kemungkinan adanya penambahan jenis inteligensi yang lainnya lagi, mengingat penelitian multiple intelligences dapat dikatakan masih baru lahir (Carvin, 2000).

Berdasarkan pemahaman atas konsep multiple intelligences sebagaimana diuraikan di depan beberapa ahli membuat simpulan sebagai berikut: (1) inteligensi merupakan sesuatu yang dinamis, terus tumbuh dan berubah sepanjang hayat, dan bukan sesuatu yang statis yang dibawa sejak lahir; (2) inteligensi dapat diperbaiki, diperluas, dan diperkuat; (3) keterbatasan inteligensi dibuat oleh individu sendiri (Lazear, 1991); dan (4) setiap orang memiliki semua jenis inteligensi, yang dapat dikuatkan, inventori suatu profil inteligensi seseorang hanya bermakna diwaktu tersebut, inteligensi cenderung dapat diubah, dan multiple intelligences orang bermakna dapat diberdayakan dan bukan sebagai label mereka.

\section{DAMPAK MULTIPLE INTELLIGENCES DALAM PEMBELAJARAN}

Teori multiple intelligences berdampak luas di bidang pendidikan. Pertanyaan para praktisi dan pembuat kebijakan pendidikan adalah bagaimana mengukur profil multiple intelligences siswa. Gardner (1999) menyadari bahwa aspek-aspek tertentu dari inteligensi dapat diukur. Alat ukur jenis short test (tes jawaban singkat) yang dikatakan banyak ahli psikologi mampu mengukur kecerdasan atau inteligensi, kenyataannya hanya mengukur inteligensi linguistik dan logika. Risiko lain menggunakan tes-tes tersebut karena dapat memberi label menarik pada anak, tetapi mengikat kemampuan anak. Di samping itu, cara mengevaluasi kemampuan anak dengan alat tes tersebut akan membatasi pola pikir seseorang dan berbahaya bila dimaknai sebagai standar penilaian.

Dalam persoalan alat tes, Gardner bekerjasama dengan David Feldman dan Kreshevsky (dalam Gardner 1999) untuk mengassessment inteligensi anak dapat dilakukan dengan menggunakan pendekatan spectrum classroom. McGrath dan Noble (1996) mengembangkan sejumlah strategi assessment untuk mengidentifikasi profil multiple intelligences seseorang. Beberapa instrumen untuk mengassessment multiple intelligences yaitu: (1) Multiple Intelligences Checklist for Adults $(M I C A)$ yang digunakan untuk mengungkap kompetensi dan preferensi multiple intelligences anak usia 11-12 tahun; (2) Multiple Intelligences Checklist for Upper Primary and Secondary (MICUPS), yang digunakan untuk mengungkap kecenderungan profil multiple intelligences siswa usia 4-10 tahun; (3) Multiple Intelligences Checklist for Youngsters (MICY), yang digunakan untuk mengungkap kecenderungan profil siswa usia 2-4 tahun; (4) Multiple Intelligences Questionaire for Early Learners(MIQUEL), yang digunakan untuk mengassessment profil multiple intelligences anak secara individual; dan (5) Checklist of Observation of Students Multiple Intelligences in the Classroom (COSMIC), yang digunakan untuk membantu guru melakukan observasi kekuatan siswa dalam partisipasinya dalam berbagai aktivitas belajar di kelas.

Teori multiple intelligences juga berdampak pada cara berfikir para pendidik. Dewasa ini para pendidik seperti McGrath dan Noble (1996) melontarkan pertanyaan yang relevan dengan perubahan cara berfikir para pendidik yaitu "How is this student smart?" dan bukan "How smart is this student?". Maksud pertanyaan tersebut menyangkut paradigma pembelajaran yaitu bahwa siswa 
memiliki gaya belajar yang berbeda-beda selaras dengan kekuatan satu atau lebih jenis inteligensi yang dimiliki. Dalam belajar, siswa menyerap informasi (isi kurikulum), menyimpan, memanipulasi, dan memperlihatkan pemahaman mereka (hasil belajar) khususnya melalui inteligensi yang dominan kuat (Veenema dan Gardner, 1996).

Teori multiple intelligences berdampak pada praktik-praktik pendidikan di sekolah khususnya di Amerika dan Australia, akhir-akhir ini telah merambah di dunia pendidikan Indonesia. Gardner sebagai pencetus teori multiple intelligences memberikan masukan kepada para pengembang dan praktisi pendidikan yang berorientasi multiple intelligences yaitu bahwa gagasan dan praktikpraktik penerapan multiple intelligences di sekolah hendaknya tidak sebagai tujuan akhir maupun berfungsi sebagai tujuan sekolah atau menjadikannya sebagai sistem pendidikan, tetapi hendaknya setiap lembaga sekolah memiliki misi dan tujuan sendiri, kemudian gagasan-gagasan pembelajaran dengan pendekatan multiple intelligences diimplementasikan (Gardner, 1999).

Teori multiple intelligences dalam bidang pembelajaran bukanlah konsep baru. Pengajaran multi modal oleh Plato (dalam Armstrong, 2004), John Dewey dengan learning by doing, model induktif, model investigasi (Joyce, Well, dan Calhoun, 2009); pembelajaran kooperatif (Haynes dan Gebreyesus, 1992), dan model pengelolaan informasi. Model-model pembelajaran tersebut dapat dikatakan sebagai sebagai model belajar yang menstimulasi satu atau lebih jenis inteligensi siswa. Model-model pembelajaran tersebut telah diidentifikasi berpengaruh positif terhadap performa akademik siswa. Persoalannya adalah mengapa proses pembelajaran di sekolah tidak menekankan pada upaya menstimulasi berbagai jenis inteligensi siswa? Bila upaya ini dilakukan guru, maka proses pembelajaran akan lebih efektif (Gardner, 2003; Armstrong, 2004).

\section{PEMBELAJARAN MELALUI PENSTIMULASIAN MULTIPLE INTELLIGENCES SISWA}

Dalam proses pembelajaran yang menstimulasian multiple intelligences siswa, mendorong guru untuk mendesain bahan pelajaran (isi kurikulum) yang akan disajikan berbeda dengan proses pembelajaran yang konvensional. Dalam proses pembelajaran yang menstimulasi multiple intelligences, guru secara dinamis terus menerus dan dengan cara yang kreatif, selalu berpindah dari satu metode ke metode lain. Pandangan teori multiple intelligences tentang penggunaan metode pembelajaran adalah bahwa guru dapat menggunakan berbagai macam metode untuk diterapkan. Ini berarti tidak ada satu metode pembelajaran yang paling cocok untuk semua siswa. Kemampuan guru dalam proses pembelajaran akan tercermin pada keterampilannya melakukan improvisasi dalam mengunakan berbagai metode pembelajaran. Persoalan terhadap pemilihan metode pembelajaran, Armstrong memberikan nasihat kepada guru yaitu hendaknya menggunakan variasi metode selaras dengan variasi kekuatan inteligensi. Model pembelajaran multiple intelligences adalah "...opens the door to a wide variety of teaching strategies that can be easily implemented in the classroom " (Armstrong, 1994).

Kunci penting dalam merancang pelajaran untuk kelas multiple intelligences ialah berfikir tentang bagaimana kita menerjemahkan isi kurikulum menjadi pengalaman belajar yang menstimulasi profil multiple intelligences siswa. Armstrong (2002) menyarankan tujuh tahap pembelajaran mendasarkan pada teori multiple intelligences: (1) memusatkan pada tujuan khusus; (2) merumuskan pertanyaanpertanyaan kunci tentang multiple intelligences; (3) mempertimbangkan kemungkinan aplikasinya; (4) melakukan brainstorm; (5) memilih kegiatan yang sesuai; (6) menetapkan urutan rencana kegiatan; dan (7) mengimplementasikan rencana. Dalam kegiatan ini guru dituntut untuk memahami konsep multiple intelligences dan memiliki variasi pengetahuan dan keterampilan tentang metode pembelajaran, serta kreatif. Armstrong juga memberikan contoh panduan pembelajaran model multiple intelligences yang disebut dengan "key materials and methods of multiple intelligences teaching". Dia mengklasifikasi kerangka pembelajaran multiple intelligences menjadi empat dimensi, yaitu dimensi: (1) inteligensi (delapan inteligensi); (2) aktivitas pembelajaran; (3) bahan ajar, dan (4) strategi pembelajaran. 
Senada dengan Armstrong, McGrath dan Noble (1996) menjelaskan bagaimana mengaitkan multiple intelligences dengan prinsip-prinsip dan praktik pendidikan sekarang. Mereka juga menerapkan strategi dengan terlebih dengan dahulu mengidentifikasi kekuatan inteligensi yang dimiliki siswa, serta memberikan 110 garis-garis besar pembelajaran ditujukan pada tujuh inteligensi. Perencanaan pembelajaran model multiple intelligences juga telah dilakukan oleh Key School di Indianapolis. Di sekolah ini, guru mencari cara untuk mengidentifikasi kekuatan setiap siswa dengan menggunakan visual, verbal, tactile senses siswa dan menggunakan pendekatan pembelajaran deduktif dan induktif (Darling-Hammond, 1997). Cara ini memberikan jalan menuju keberhasilan belajar setiap siswa. Senada dengan uraian di atas, Campbell, Campbell, \& Dickinson (1996) memberikan acuan merancang desain kurikulum dengan format sebagai sebagaimana disajikan pada gambar 1.

Mengingat setiap siswa memiliki profil kekuatan multiple intelligences yang berbeda, maka Gardner (1999) menambahkan pendekatan terfokus pada "titik masuk" melalui multiple intelligences. Ada tujuh titik masuk, yaitu: narational, quantitative atau numerical, logical, foundational atau existential, aesthetic, hands on, dan social. Penciptaan pengalaman belajar melalui berbagai titik masuk tersebut akan menumbuhkan ketertarikan, rasa aman secara kognitif, dan menyenangkan bagi siswa untuk mengeksplorasi informasi lebih jauh. Pandangan tentang aplikasi teori multiple intelligences dalam proses pembelajaran mendorong para pakar bidang psikologi pendidikan maupun bidang pembelajaran tertarik untuk mengembangkan teori perskriptif pembelajarannya. Para pakar yang dimaksud antara lain Linda Campbell, Bruce Campbell, Dickinson, Armstrong, McGrath dan Noble.

Bruce Campbell, 1996 melakukan penelitian pengembangan model pembelajaran bagi siswa kelas III, IV dan V Sekolah Dasar dengan menciptakan tujuh pusat belajar, setiap pusat menyajikan model pembelajaran untuk setiap jenis inteligensi. Hasil penerapan model ini bahwa para siswa tidak hanya memperoleh skor tes tinggi, meningkatnya keterampilan di bidang-bidang kehidupan mereka. Dampak jangka panjang proyek riset aksi tersebut antara lain: para siswa menemukan kekuatan dan menemukan berbagai kegiatan di dalam kelas yang melibatkan penggunaan berbagai inteligensi siswa, masalah-masalah tingkah laku siswa dapat dikurangi, self-concept mereka meningkat, keterampilan memimpin dan kerjasama berkembang, dan di atas semua itu kecintaan siswa untuk belajar dapat ditingkatkan (Campbell, Campbell, dan Dickinson, 1996).

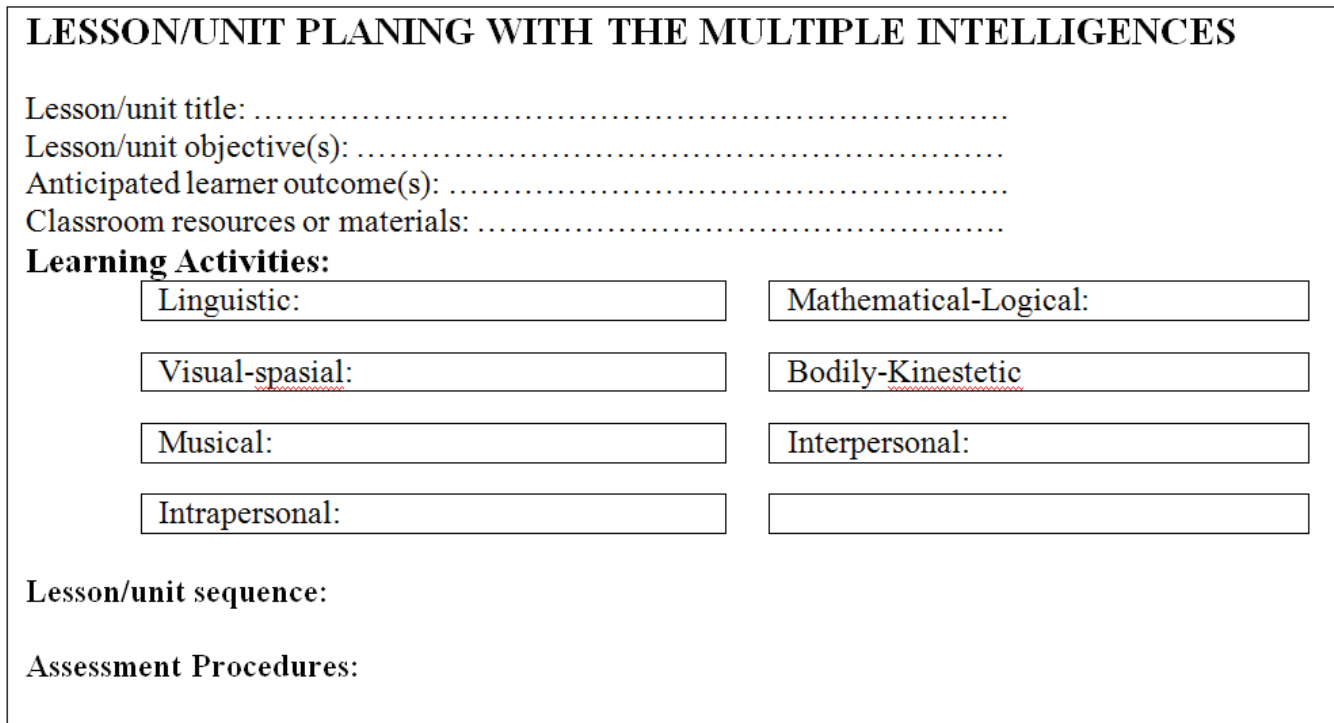

Sumber: Campbell, Campbell, \& Dickinson, 1996

Gambar 1 Satuan Pembelajaran (Kurikulum Instruksional) Model Multiple Intelligences 
Linda Campbell dalam penelitiannya tentang pendidikan guru Sekolah Dasar dan pendidikan guru Sekolah Menengah untuk belajar bagaimana menggunakan tujuh jenis inteligensi dalam setiap pelajaran yang mereka ajarkan, menunjukkan hasil bahwa para guru yang menjadi subjek penelitian merasa tidak hanya belajar merencanakan strategi pembelajaran dan strategi assessment, tetapi mereka juga belajar berdasarkan proyek, belajar mengembangkan model pengembangan kurikulum interdisipliner, dan juga belajar bagaimana mengenali perbedaan inteligensi siswa yang mereka ajar (Campbell, Campbell, \& Dickinson, 1996).

Armstrong (1993) dalam bukunya "Multiple Intelligences in the Classroom" memberikan panduan bagaimana merancang strategi pembelajaran dan pengelolaan kelas berdasarkan teori multiple intelligences. Buku tersebut disusun berdasarkan hasil studi tentang penerapan teori multiple intelligences dalam pembelajaran selama lebih dari 8 tahun. Pengalaman yang sama dengan Armstrong; Campbell, Bruce Campbell, dan Dee Dickinson menulis buku berjudul "Teaching and Learning Through Multiple Intelligences" tahun 1996. Demikian pula McGrath dan Noble (1996) dalam buku mereka "Seven Ways at One: Classroom Strategies Base on the Seven Intelligences (Book I)" memuat bagaimana merencanakan proses pembelajaran yang mengacu pada penstimulasian multiple intelligences siswa.

Berdasarkan uraian tersebut di atas dapat disimpulkan bahwa pembelajaran yang berdasarkan pada teori multiple intelligences dapat dikatakan sebagai inovasi dan reformasi di bidang pembelajaran dan menantang bagi para ahli pendidikan dan psikologi pendidikan untuk mengkajinya lebih mendalam.

\section{STRATEGI EVALUASI HASIL BELAJAR BERBASIS MULTIPLE INTELLIGENCES}

Proses pembelajaran dengan pendekatan multiple intelligences mengandung konsekuensi pada strategi evaluasi hasil belajar. Dalam pendekatan ini, guru tidak memaksa siswa untuk memperlihatkan apa yang telah mereka pelajari atau ketahui hanya dengan menggunakan alat tes, melainkan dengan berbagai instrumen. Kekurangan tes buatan guru maupun tes standar sebagai instrumen evaluasi karena sempitnya untuk mengukur apa yang diketahui siswa selama periode belajar, di samping cenderung mengukur pengetahuan deklaratif saja.

Pembelajaran pendekatan multiple intelligences menyarankan bahwa tujuan pengajaran dapat dicapai paling tidak melalui delapan cara belajar yang berbeda, demikian pula dalam melakukan assessment hasil belajar siswa. Berbagai cara melakukan assessment hasil belajar, misalnya dengan menggunakan media yang bersifat linguistic, logical mathematic, spatial, bodi-kinesthetic, musical, interpersonal dan intrapersonal, dan naturalistic. Dengan kata lain bahwa teori multiple intelligences merestrukturisasi cara melakukan assessment hasil belajar secara fundamental. Dengan berbagai cara melakukan assesment hasil belajar siswa tersebut mendorong guru untuk tidak lagi hanya mengungkap aspek pengetahuan deklaratif yang dimiliki siswa, tetapi juga mengungkap pengetahuan prosedural dan kontekstual dengan porsi yang relatif seimbang. Dalam konteks ini, pendekatan evaluasi hasil belajar yang dianjurkan dalam aplikasi multiple intelligences dalam pembelajaran untuk menggunakan authentic assessment dan portofolio.

Authentic assessment maupun portofolio dapat digunakan untuk menyelidiki pemahaman dan keterampilan siswa terhadap mata pelajaran jauh dari sekedar melalui multiple choice test atau fillin-the-blank test (Armstrong, 1993). Secara khusus, dengan menggunakan kedua cara tersebut, siswa mampu menunjukan apa saja yang telah mereka pelajari dalam kehidupan nyata. Portofolio dapat meningkatkan keleluasaan dalam membaca, menulis, memecahkan soal matematika dan dapat dicermati dengan detail, memberikan informasi yang konkret tentang kemajuan siswa sehingga dapat digunakan untuk arahan dan peningkatan pengajaran dari hari ke hari (Darling-Hammond, 1997). Dalam banyak kasus portofolio sebagai refleksi aktual aktivitas belajar siswa dari hari ke hari 
(Armstrong, 1994). Sementara, jika pengukuran dengan mengunakan "tes standar" sebagaimana yang terjadi di sekolah-sekolah Indonesia seperti adanya Ujian Nasional banyak melakukan assessment atau mengukur kemampuan siswa dalam aspek yang artifisial jauh dari dunia riil.

\section{SIMPULAN}

Strategi pembelajaran melalui penstimulasian multiple intelligences termasuk strategi dan teknik evaluasinya adalah proses pembelajaran yang memerhatikan kekuatan, gaya belajar dan cara mudah belajar, serta mengaktualisasikan pengalaman belajar siswa yang hakiki. Sementara ini pembelajaran konvensional yang terjadi di sebagian besar sekolah formal Indonesia cenderung bersifat ceramah dan pemberian tugas. Tagihan hasil belajar diungkap dengan ujian atau tes paper pencil test bentuk pilihan ganda. Tagihan seperti ini cenderung hanya mengungkap aspek-aspek kognitif yang terbatas seperti kemampuan mengingat dan memahami, namun kurang pada aspek analisis, evaluasi, maupun kreativitas.

Authentic assessment menjadi kesatuan proses pembelajaran melalui penstimulasian multiple intelligences lebih memfasilitasi para siswa mengungkapkan atau mengaktualisasikan hasil pengalaman belajarnya melalui berbagai cara sesuai dengan kekuatan jenis inteligensinya. Siswa yang kuat inteligensi spasialnya dapat mengaktualisasikan pengalaman belajarnya dengan membuat mind map, grafik, tabel, maupun gambar-gambar yang memuat pengetahuan yang dimiliki berdasarkan hasil belajar. Sementara mereka yang kuat inteligensi interpersonalnya dapat mengaktualisasikan hasil belajarnya melalui presentasi dan saat berdiskusi. Lain halnya mereka yang kuat kinesthetic intelligencenya dapat mengekspresikan pengalaman belajarnya melalui gerakan-gerakan anggota tubuhnya, demikian selanjutnya.

Proses pembelajaran yang menstimulasi multiple intelligences siswa di sekolah-sekolah formal dapat dilakukan oleh sebagian besar guru. Penyiapan guru agar memahami konsep, prinsip, media pembelajaran, metode pembelajaran, authentic assessment yang menstimulasi multiple intelligences perlu dilakukan. Seminar, diklat, dan workshop pembelajaran penstimulasian multiple intelligences perlu dilakukan secara masif dan intensif, dan berkelanjutan.

\section{DAFTAR RUJUKAN}

Armstrong, T. (1994). Multiple Intelligences in The Classroom. Alexandria, Virginia: ASCD

Armstrong, T. (2002). Setiap Anak Cerdas Panduan Membantu Anak Belajar dengan Memanfaatkan Multiple Intelligencenya (Alih bahasa Rina Buntaran). Jakarta: PT Gramedia Pustaka Utama

Armstrong, T. (2002). Seven Kinds of Smart: Menemukan dan Meningkatkan Kecerdasan Anda Berdasarkan Teori Multiple Intelligences. (Edisi kedua). (Terjemahan oleh: T. Hermaya). Jakarta: PT Gramedia Pustaka Utama

Armstrong, T. (2003). Sekolah Para Juara (2nd Ed.) (Terjemahan olehYudi Murtanto). Bandung: Penerbit Kaifa

Armstrong, T. (2004). Membangkitkan Kejeniusan di Dalam Kelas (terjemahan oleh: Margaritifere R.L. Nugroho). Batam Centre: Interaksara.

Armstrong, T. (2009). Multiple Intelligences in The Classroom (3rd Ed). Alexandria, Virginia: ASCD

Campbell, L., Campbell, B., \& Dickinson, D. (1996). Through Multiple Intelligences. Needham Heights, MA: Allyn \& Bacon.

Campbell, B. (1992). Multiple Intelligences in Action. Childhood Education, 68(4), 197-201.

Carvin, A. (2000). Intelligences Theory. (http//edweb.gsn.org/edref.mi.ed..html)

Carvin, A. (2000). MI and Education: The Connection (http//edweb.gsn.org/edref.mi.th..html)

Darling-Hammond, L. D. (1997). The Right to Learn: A Blueprint for Creating Schools That Work. San Francisco, California: Jossey-Bass Inc., Publishers. 
De Fina, A. A. Tanpa Tahun. Portfolio Assessment: Getting Started. New York: Scholastic Professional Books.

Gardner, H. (1993). Multiple Intelligences: The Theory in Practice. New York: Basic Books, A Division of Harper Collins Publisher.

Gardner, H. (1999). Intelligence Reframed: Multiple Intelligences for The 21th Century. New York: Basic Books.

Haynes, N. M. \& Gebreyesus, S. (1992). Cooperative Learning: A Case for African-American Students. School Psychology review, 21(4), 577-585

Joyce, B., Well, M., \& Calhoun, E. (2009). Models of Teaching Model-model Pengajaran. Edisi kedelapan. (Penerjemah: Achmad F dan Ateilla M). Yogyakarta: Pustaka Pelajar

Lazear, D. G. (1991). Seven Ways of Knowing: Teaching for Multiple Intelligences. Palatine, Ill: Skylight Publishing, Inc.

McGrath, H. \& Noble, T. (1996). Seven Ways at Once Classroom Strategies Based on The Seven Intelligences. Sydney, Brisbane: Addison Wesley Longman Australia.

McKenzie W. (2005). Multiple Intelligences An Instructional Technology (2nd ed.). Eugene OregonWashington DC: International Society for Technology in Education.

Rose, C. P., \& Nicholl, M. J. (1998). Accelerated Learning for The 21st century: The Six-step Plan to Unlock Your Master-mind. Dell Books.

Slavin, R. E, 2008. Psikologi Pendidikan Teori dan Praktik. Edisi ke delapan. (Penerjemah: Marianto Samosir). Jakarta: PT Indeks.

Tsantis L. A \& Keefe D. D. (1992). Pre school Children ... Masters of Change. Teaching Thinking An Agenda for 21 st century. Collins C. \& Mangieri J.N (edt). Hillsdale. New Jersey:Lawrence Erlbaum Associates Publisher.

Veenema, S. \& Gardner, H. (1996). Multimedia and Multiple Intelligences. American prospect, 29(7), 69-75. 